\title{
Kommentar
}

\section{Svimmelhet til besvær}

Ortostatisk (postural) hypotensjon er et vanlig helseproblem, særlig i den eldre del av befolkningen. Tilstanden varierer i alvorlighetsgrad fra helt lette symptomer til alvorligere, som falltendens og besvimelse. Svimmelhet er mest typisk, men pasientene kan også få symptomer som tretthet, muskelsvakhet, konsentrasjonsvansker eller synsforstyrrelser, og i tilfeller med vedvarende ortostatisk hypotensjon eller større blodtrykksfall kan synkope inntreffe $(1,2)$. Ortostatisk hypotensjon er vanlig ved sykdommer som medfører svekket funksjon i det autonome nervesystemet, som Parkinsons sykdom, multisystematrofi (MSA) og autonome nevropatier. Når disse er årsaken, kalles tilstanden nevrogen ortostatisk hypotensjon. En viktig grunn til å avklare om det foreligger nevrogen årsak, er faren for større svingninger i blodtrykket pga. svekket baroreseptorfunksjon $(1,2)$. En konsekvens av dette er økt forekomst av hypertensjon i liggende stilling.

Nilsen og medarbeidere omtaler en eldre mann som i ti år ble behandlet for høyt blodtrykk og bivirkninger av blodtrykksmedisiner før man kom frem til diagnosen nevrogen ortostatisk hypotensjon som ledd i multisystematrofi. Viktige kliniske kjennetegn ved multisystematrofi er ulike kombinasjoner av autonom svikt, parkinsonisme, cerebellær ataksi og sentralnervøst betingede nevrologiske utfall, som forøkede reflekser (3). I artikkelen diskuteres det om ortostatisk hypotensjon var første symptom på multisystematrofi eller om det forelå flere årsaker til svim- melheten. Det er ikke uvanlig at ortostatisk hypotensjon opptrer tidlig ved multisystematrofi, men som oftest vil sykdommen progrediere raskere enn i dette tilfellet. På den annen side fremkom det opplysninger om at pasienten hadde ereksjonsproblemer, hvilket er et vanlig symptom ved multisystematrofi.

Man kommer langt i diagnostikken av ortostatisk hypotensjon med en grundig sykehistorie samt somatisk og nevrologisk undersøkelse. Særlig bør man kartlegge om det foreligger symptomer eller tegn på autonom dysfunksjon. Blodtrykket må måles i liggende og stående stilling rutinemessig. 24-timers blodtrykksregistrering kan også være nyttig, i tillegg rutineblodprøver og EKG (4). Ved mistanke om nevrogen årsak er det også viktig å kartlegge andre årsaker og vice versa. Dette fordi flere av årsakene til ortostatisme er vanlige og derfor kan forekomme samtidig (4). Før man vurderer medikamenter mot høyt eller lavt blodtrykk er det viktig å gi pasienten gode råd for å mestre tilstanden. En viktig grunn til dette er fare for blodtrykksfall hos dem med stor variasjon i blodtrykket. Hovedmålet med behandlingen av nevrogen ortostatisk hypotensjon bør derfor være symptomlindring og forbedring av pasientens funksjonsnivå (4). Som det fremheves i diskusjonen i kasuistikken bør enkle tiltak som å heve hodeenden på sengen med $10 \mathrm{~cm}$ eller mer, rikelig med drikke samt tilstrekkelig saltinntak gjennomføres (4). Sykehistorien til denne pasienten understreker viktigheten av å ha en helhetlig tilnærming til pasienter med ortostatisk hypotensjon.

\section{Svein Ivar Bekkelund}

svein.ivar.bekkelund@unn.no

Nevrologisk og nevrofysiologisk avdeling

Universitetssykehuset Nord-Norge

og

Institutt for klinisk medisin

Universitetet i Troms $\varnothing$

Svein Ivar Bekkelund (f. 1961) er spesialist i nevrologi, avdelingsleder ved Nevrologisk og nevrofysiologisk avdeling, Universitetssykehuset Nord-Norge, og professor ved Universitetet i Troms $\varnothing$.

Forfatter har fylt ut ICMJE-skjemaet og oppgir ingen interessekonflikter.

Litteratur

1. Low PA, Singer W. Management of neurogenic orthostatic hypotension: an update. Lancet Neurol 2008; 7: 451-8.

2. lodice V, Low DA, Vichayanrat E et al. Cardiovascular autonomic dysfunction in MSA and Parkinson's disease: similarities and differences. J Neurol Sci 2011; 310: 133-8

3. Köllensperger M, Geser F, Ndayisaba JP et al. Presentation, diagnosis, and management of multiple system atrophy in Europe: final analysis of the European multiple system atrophy registry. Mov Disord 2010; 25: 2604-12

4. Lahrmann H, Cortelli P. Hilz M et al. EFNS guidelines on the diagnosis and management of orthostatic hypotension. Eur J Neurol 2006; 13: 930-6.

Mottatt 2.5. 2012 og godkjent 14.5. 2012. Medisinsk redaktør Merete Kile Holtermann. 